\title{
KRIMINALPOLITIK, STRAFFEPROCES OG REAKTIONSVALG I DET NY ÅRTUSIND
}

\author{
Af LEKTOR, LIC.JUR. Beth Grothe Nielsen
}

Dette tidsskrift bragte i nr. 4/1999 (s. 309-319) en kronik om nogle hovedtendenser inden for områder af strafferetten, som i de seneste år i særlig grad har haft danske mediers og politikeres bevågenhed. Det drejer sig om volds- og seksualforbrydelser, organiseret kriminalitet og rockerkriminalitet, ungdomskriminalitet, narkotikakriminalitet og erhvervslivets kriminalitet. I forlængelse heraf skal der i det følgende gives en oversigt, for så vidt angår nogle straffeprocessuelle spørgsmål, strafferetlige reaktioner og straffesystemets administration.

\section{Straf og andre reaktioner}

Indtil for nylig har Danmark ikke haft en samlet lovgivning om straffuldbyrdelse. Straffeloven har indeholdt enkelte bestemmelser suppleret med administrativt fastsatte regler $\mathrm{i}$ to bekendtgørelser og et stort antal cirkulærer. Dette er nu ændret. I 1989 - efter ni års arbejde - afgav en arbejdsgruppe nedsat af Straffelovrådet betænkning om en lov om fuldbyrdelse af straf mv. (nr. 1181/1989 - 3 bind). Arbejdsgruppens forslag blev - i yderligere ca. ni år - behandlet af Straffelovrådet (betænkning nr. 1355/1998). Efter en - ganske kort - høringsrunde fremlagde Justitsministeren forslag til lov om fuldbyrdelse af straf mv. og til lov om ændring af forskellige lovbestemmelser, nu vedtaget som lov nr. 432 og 433 af 31.5.2000 med ikrafttræden pr. 1.7.2001. Også denne lov er nu suppleret med en stor mængde bekendtgørelser, cirkulærer, vejledninger, skrivelser etc.

Lov om fuldbyrdelse af straf mv. omfatter følgende former for straf og reaktioner: fængselsstraffe, bødestraffe, betingede domme, samfundstjeneste og forvaring. Lovens bestemmelser har til formål at styrke retssikkerheden for de dømte under fuldbyrdelsen i og med, at de basale regler på området har făet lovstatus. På den anden side er det blevet fremført - bl.a. fra Direktoratet for Kriminalforsorgens side - at der nu ikke længere hurtigt kan ske administrativ ændring af cirkulærer mv. for at imødekomme ændrede behov (heller ikke, selv om det er til fordel for de indsatte). Loven indeholder i § 3 en hensigtsbestemmelse, der lyder: "Fuldbyrdelse af en straf skal ske med fornøden hensyntagen såvel til straffens gennemførelse som til behovet for at hjælpe eller påvirke den dømte til at leve en kriminalitetsfri tilværelse". Dette kan sammenholdes med Kriminalforsorgens principprogram fra 1993, hvori det hedder:

Kriminalforsorgens hovedopgave er at fuldbyrde straf. I den forbindelse skal Kriminalforsorgen - udøve den kontrol, der er nødvendig for at fuldbyrde straffen.

- støtte og motivere den dømte til gennem personlig, social, arbejds- og uddannelsesmæssig udvikling at leve en kriminalitetsfri tilværelse.

Disse to led i hovedopgaven er sidestillet, og der er således ikke tale om, at nogen del af opgaven er vigtigere end den anden.

Den nye lov skal ikke gennemgås i detaljer (men se Vagn Greve i dette tidsskrift nr. 1/2001, s. 1-22). Det skal blot nævnes, at loven, for så vidt angår afsoning af fængselsstraf, bl.a. indeholder afsnit om valg af afsoningsinstitution, overførsel af indsatte fra én institution til en anden, indsattes rettigheder og pligter under opholdet $\mathrm{i}$ afsoningsinstitutionen, indsattes kontakt til samfundet uden for institutionen, indgreb over for indsatte, disciplinærstraf og løsladelse. Næsten alle bestemmelser af denne art forudsætter stadig, at detaljerne reguleres administrativt, og absolutte rettigheder for de indsatte er der ikke mange af, idet de fleste kan begrænses "af ordens- og sikkerhedsmæssige hensyn”. Det gælder f.eks. retten til at deltage i gudstjeneste, retten til at udgive et fængselsblad, retten til brevveksling (undtagen med visse myndigheder), retten til at føre telefonsamtaler og retten til kontakt med medierne. Til gengæld er forskellige indgreb og disciplinærmidler over for indsatte reguleret temmelig detaljeret i selve loven, men også på dette område er der hjemmel til yderligere administrativ regulering. 
På nogle få områder indføres der adgang til domstolsprøvelse af endelige administrative afgørelser, dvs. efter at den almindelige klageadgang er udtømt. Ingen af de ovenfor nævnte rettigheder (bortset fra modtagelse af brev i et særtilfælde) kan - hvis de nægtes - undergives domstolsprøvelse. Adgangen til domstolsprøvelsen handler først og fremmest om disciplinærstraf, nægtelse af prøveløsladelse og nægtelse af erstatning for uforskyldt udståelse af fængselsstraf i for lang tid eller uberettiget anbringelse i strafcelle. Herudover er der indført adgang til prøveløsladelse af fanger, som er idømt fængsel på livstid. Disse har hidtil kun kunnet løslades efter benådning. Der foreskrives nu pligt til at tage spørgsmålet om prøveløsladelse op, når 12 år af livstidsdommen er afsonet.

De almindelige straffe i den danske straffelov har hidtil været fængsel, hæfte og bøde. Der har gennem årene været fremsat flere forslag om at afskaffe hæftestraffen. Denne type frihedsberøvelse blev oprindelig indført med det formål, at der med to forskellige betegnelser for frihedsstraf og forskellig grad af restriktiv afsoning af de to former for frihedsstraf kunne signaleres forskelle mellem de "egentligt kriminelle" og de andre. Efterhånden har indholdet af fængsel og hæfte nærmet sig så meget til hinanden, at det ikke længere anses for formålstjenligt at opretholde dem begge, og med den nye lovs vedtagelse er hæftestraffen nu ophævet. Denne ændring af strafformer bygger på et forslag i Straffelovrådets betænkning nr. 1099/1987 om strafferammer og prøveløsladelse.

Tidsubestemte sanktioner som f.eks. dom til ungdomsfængsel blev stort set alle ophævet i 1973. Tilbage er forvaring af særlig farlige personer (straffelovens § 70) og foranstaltninger for personer, der frifindes på grund af utilregnelighed i gerningsøjeblikket, eller som befandt sig i en nærmere beskrevet psykisk tilstand (straffelovens $\S \S 68$ og 69) på dette tidspunkt. På baggrund af Straffelovrådets betænkning nr. 1372/1999 er der indført en længstetid på 5 år for foranstaltninger af denne type, når de medfører eller kan medføre institutionsanbringelse, dog med mulighed for forlængelse $\mathrm{i}$ indtil 2 år under særlige omstændigheder. Begrundelsen er først og fremmest hensynet til retssikkerheden, idet en undersøgelse har vist, at foranstaltninger iværksat på baggrund af mindre alvorlige forbrydelser i nogle tilfælde har været ganske langvarige, uden at dette ses begrundet i den dømtes farlighed. Netop farlighedsvurderingen synes da også at være afgørende for, at der ikke skal fastsættes en længstetid, hvis personen er dømt for f.eks. drab, voldtægt og alvorlig vold. Ændringerne blev vedtaget med lov nr. 438 af 31.5.2000.

Danmark er et af de lande i Europa, der idømmer flest fængselsstraffe i forhold til indbyggertallet. Til gengæld er en stor del af dem meget kortvarige. De seneste opgørelser viser, at f.eks. på voldsområdet er antallet af domme til ubetinget fængsel i forhold til anmeldelsestallet steget og dommenes længde øget. Blandt andet denne udvikling fik fire af landets fængselsinspektører til at gå til pressen (Jyllands-Posten 13.3.2000) med det budskab, at Danmark straffer for hårdt sammenlignet med Norge og Sverige, at vi har alt for mange korte fængselsstraffe, der nemt kunne undværes, og at vi trænger til en debat om straffens nytte. En af inspektørerne udtaler, at han ikke tror på fængselsstraffen hverken som afskrækkelse eller forbedring, kun som hævn. De fire sender et kraftigt budskab til politikerne om det fejlagtige $\mathrm{i}$ at tro på strengere straf som middel til at bekæmpe f.eks. voldskriminalitet, og de anbefaler flere betingede domme, mere samfundstjeneste og indførelse af andre, ikke frihedsberøvende, reaktioner. Fængselspræsterne har tidligere været ude med samme budskab (JyllandsPosten 18.9.1998). Ikke desto mindre fortsætter den politiske højrefløj med jævnligt at fremsætte forslag til strafskærpelser, f.eks. med et forslag fremsat 2. februar 2001 (L 161) af partierne Venstre og Det konservative Folkeparti, hvori bl.a. maximum-straffen for simpel vold ønskes hævet fra 1 år og 6 måneder til 3 år og for voldtægt fra 6 til 8 år (under skærpende omstændigheder fra 10 til 12 år). Forslaget blev dog forkastet (31. maj 2001) af regeringspartierne (Socialdemokrater og Radikale) med støtte af venstrefløjen (Socialistisk Folkeparti og Enhedslisten). Dermed er endnu engang markeret, hvordan det danske Folketing er delt i synet på (øget brug af) fængselsstraf.

Et af de alternativer til ubetinget fængselsstraf, som der fra flere sider efterlyses mere brug af, er samfundstjeneste. Efter en forsøgsperiode blev samfundstjeneste indført som selvstændig strafferetlig reaktion i 1992. Med lov nr. 274 af 15.4.1997 og lov nr. 230 af 4.4.2000 er der senere indført ændringer, som skal sikre øget anvendelse af denne sanktion, ifølge sidstnævnte lov som reaktion i forbindelse med spirituskørsel. Siden starten er antallet af domme til samfundstjeneste steget støt, 
og især i de seneste år har denne stigning været stor. Dom til samfundstjeneste gives fortrinsvis for berigelseskriminalitet, især bedrageri, underslæb og mandatsvig, men relativt sjældent for tyveri. Seksual-, narkotika- og voldsforbrydelser medfører stort set aldrig dom til samfundstjeneste, og ifølge bemærkningerne til de seneste ændringer i loven bør samfundstjeneste stadig anvendes "med varsomhed" på disse områder. Flere undersøgelser har slået fast, at potentialet for brug af samfundstjeneste langt fra er udtømt, og at det ofte skyldes, at ingen kommer i tanke om at anmode om en egnethedsvurdering (personundersøgelse) af den tiltalte. Dette skal der ifølge Justitsministeriet rettes op på, hvilket anklagemyndigheden instrueres om.

Kriminalitet blandt børn og unge er fortsat højt på dagsordenen i medier og blandt politikere. I oktober 2000 nedsatte regeringen en ekspertgruppe, ifølge kommissoriet med følgende begrundelse:

I den senere tid har vi set en udvikling, hvor børn og unge i stigende grad begår alvorlig, personfarlig kriminalitet, herunder gaderøveri og gruppevoldtægt. Denne udvikling rejser spørgsmål om, hvorvidt reaktionsmulighederne over for den hårdeste kerne af socialt belastede og utilpassede unge kriminelle er tilstrækkeligt effektive. Det gælder både i forhold til unge kriminelle af dansk og af udenlandsk herkomst. Og det gælder både i forhold til unge over og under den kriminelle lavalder.

En rapport om ungdomskriminalitet, udarbejdet af denne ekspertgruppe, forelå allerede $\mathrm{i}$ januar 2001. Et flertal foreslår en ny ungdomssanktion indført i straffeloven i form af dom til socialpædagogisk behandling. Hovedelementerne i denne sanktion består af et indledende ophold i en sikret institution, derefter et længerevarende ophold i en almindelig døgninstitution eller et godkendt opholdssted og til sidst en ambulant udslusningsfase. Den samlede varighed skal være 2 år. Et mindretal finder ikke, at der er behov for en sådan ny sanktion, og at den i givet fald ikke bør være en del af straffeloven, men "et socialt koncept", der kan gives som vilkår til en betinget dom eller besluttes af Kriminalforsorgen som alternativ afsoning efter allerede gældende bestemmelser. Rapporten er et eksempel på den vanskelige sammenblanding af straf og omsorg/behandling, som altid har fundet sted, når det drejer sig om børn og unge. Ungdomssanktionen blev vedtaget med stort flertal (kun Socialistisk Folkeparti og Enhedslisten stemte imod) af Folketinget den 1. juni 2001.

\section{Kriminalforsorgens virksomhed}

Den danske Kriminalforsorg undergår i disse år meget store strukturelle ændringer såvel i direktoratet som i de enkelte fængsler. Der har været problemer med at holde udgifterne inden for budgetterne, og en analyse fra Økonomistyrelsen har - populært sagt - vist, at Kriminalforsorgen hidtil har fungeret som en tungt lastet skude, der har svært ved at ændre kurs. Der lægges op til decentralisering, mål- og rammestyring med konkret målformulering for de enkelte institutioner og kontrakter om opfyldelse af målene, resultatløn til medarbejdere med ledende funktioner (incl. direktøren selv), mindre bureaukratisk beslutningsgang og entydig ledelse i de enkelte institutioner, ansættelse af økonomichefer med akademisk uddannelse mv.

Der er foregået et omfattende arbejde, bl.a. i projektgrupper, med udmøntning og implementering af Økonomistyrelsens forslag. Direktoratets nye struktur beskrives i "Nyt fra Kriminalforsorgen" nr.4/01, og nøgleordene angives som følger (s. 13):

* Entydig opgave- og ansvarsfordeling

* Funktionsorienteret og ikke institutionsorienteret

* Samlet overblik over ressourcerne giver bedre grundlag for at prioritere indsatsen

* Sammenhæng mellem ressourcer, faglige mål og resultater - større mulighed for hurtig omstillling

* Tværfaglighed til styrkelse af behandlingsindsatsen

* Uddelegering af ressourcer til tjenestestederne - og målrettet opfølgning

* Adskillelse af drift og udvikling

* Tid og rum til udviklingsopgaver og professionalisering af driften.

Siden midten af 1990'erne har der været meget fokus på de såkaldt "negativt stærke fanger" i fængslerne. Det drejer sig fortrinsvis, men ikke udelukkende, om fanger med tilknytning til rockergrupper, som hævdes at misbruge deres position i forhold til medfanger. I de senere år er der 
desuden kommet flere narkomaner, psykisk syge og andre svage grupper af fanger, som de stærke kan dominere. Blandt andet dette problem har foranlediget, at Kriminalforsorgen i 1998 nedsatte et såkaldt differentieringsudvalg, der skulle se på udviklingen i Kriminalforsorgens klientel. Udvalget afleverede i 1999 en betænkning i to bind om placering af indsatte. Bind 1 indeholder udvalgets indstilling, og bind 2 omfatter tre rapporter, nemlig henholdsvis en klientundersøgelse, en trivselsundersøgelse og en undersøgelse om vold og trusler mod Kriminalforsorgens personale.

Differentieringsudvalget foreslår, at de hidtidige principper om indsattes placering i geografisk nærhed til familien og om fortynding, dvs.blanding af dømte med forskellig kriminalitet, straflængde etc. i samme institution, bør modificeres, så de ikke længere er afgørende. Udvalget har formuleret fire nye principper, der bør tælle med større vægt: Hensynet til sikkerhed mod undvigelse og kriminalitet under afsoningen, hensynet til orden i institutionen, herunder rimelig beskyttelse af de indsatte under afsoningen, hensynet til mulighederne for målrettet behandling af de indsatte og endelig nogle - løst formulerede - humanitære hensyn.

Udvalget foreslår oprettelse af særlige afdelinger til indsatte med forskellige problemer og behov og beskyttede afdelinger til bl.a. seksualforbrydere, personalefri afdelinger til indsatte uden undvigelsesrisiko og - omvendt - specialafdelinger for særligt undvigelsestruede. Efter udvalgets mening bør der indsættes langt færre i lukkede fængsler end i dag, og der bør indrettes halvåbne afdelinger i de åbne fængsler. Der planlægges nyt fængselsbyggeri bl.a. til erstatning for de meget utidsvarende gamle danske fængler, der stammer fra midten af 1800-tallet. Endvidere er der bevilliget penge til bygning af et nyt såkaldt fleksfængsel, som skal stå færdigt i 2002 og rumme mulighed for adskillelse af stærke fanger.

Delvis på grund af problemet med de negativt stærke fanger, herunder visse fangers trusler og chikane mod fængselspersonalet, har det været overvejet, om der skulle indføres undtagelser fra de almindelige forvaltningsretlige regler om partsaktindsigt og begrundelse af afgørelser, for så vidt angår sager om straffuldbyrdelse. Et flertal i Straffelovrådet foreslog i 1996 en sådan ordning i sager om valg af afsoningsinstitution, om overførsel til anden afsoningsinstitution eller afdeling og om udelukkelse fra fællesskab. I Justitsministeriets bemærkninger til forslag til lov om straffuldbyrdelse mv. (nr. L 145 af 8.12.1999) siges det, at sådanne regler er principielt betænkelige og kun bør indføres, hvis meget væsentlige hensyn til de sikkerhedsmæssige forhold taler derfor. Derfor er de ikke medtaget $\mathrm{i}$ lovforslaget og altså heller ikke i den nu vedtagne lov, men der vil ske en løbende vurdering af udviklingen på området.

Forestillinger om, at det er muligt at påvirke indsatte i fængslerne til at leve en kriminalitetsfri tilværelse efter løsladelsen, er - efter flere årtiers "nothing works"-tankegang - ved igen at vinde indpas i dansk kriminalpolitik og i Kriminalforsorgen, hvilket bl.a. fremgår af ovennævnte hensigtserklæring i den nye lov om fuldbyrdelse af straf såvel som af Kriminalforsorgens principprogram og senest af differentieringsudvalgets betænkning. I praksis har denne udvikling bl.a. resulteret i oprettelsen af afdelinger i fængslerne til narkofri afsoning og en række forsøg i Kriminalforsorgens regi med behandling af seksualforbrydere, kriminelle stofmisbrugere, spiritusbilister, voldsforbrydere mv. Forsøgsordningerne vedrørende seksualforbrydere og narkomaner er nærmere beskrevet i dette tidsskrift nr. 4/1999 s. 311 og 317. (Se iøvrigt Nielsen 2001a og b). Egentlige kontrollerede effektundersøgelser (f.eks. måling af recidiv) med sammenlignelige grupper af behandlede og ikke behandlede indsatte efter en rimelig lang tid på fri fod foreligger endnu ikke.

\section{Domstolenes organisation og kompetence}

Danske domstole har indtil for nylig i såvel budgetmæssig som administrativ henseende hørt under Justitsministeriet. Der har gennem årene været rejst kritik af dette forhold, som kunne synes i strid med princippet om magtens tredeling og domstolenes uafhængighed. Der har bl.a. været peget på risikoen for indflydelse på domstolene i forbindelse med ministeriets rolle ved udnævnelsen af dommere, noget der i straffesager forstærkes af, at ministeriet samtidig under sit forretningsområde har politiet og anklagemyndigheden. Kritikken har medført, at der nu er sket en udskillelse af domstolene fra forvaltningen. Med lov nr. 401 af 26.6.1998 om domstolsstyrelsen blev domstolene en 
selvstændig statsinstitution, der ledes af en bestyrelsen og en direktør. Justitsministeren har ingen instruktionsbeføjelser over for domstolsstyrelsen, og styrelsens afgørelser kan ikke påklages til ministeren. Styrelsens medlemmer er repræsentanter for retsvæsenet samt personer med ledelsesmæsig og samfundsmæssig indsigt. Hverken folketingspolitikere eller lokalpolitikere kan være medlemmer. Medlemmerne beskikkes af justitsministeren efter indstilling fra relevante institutioner for 4 år med mulighed for genbeskikkelse. Styrelsen ansætter og afskediger direktøren, fastsætter selv sin forretningsorden og kan fastsætte vedtægt for domstolsstyrelsen. Samtidig med indførelsen af en domstolsstyrelse er der med lov nr. 402 af 26.6.1998 oprettet et dommerudnævnelsesråd.

I januar 2001 forelå der en omfattende betænkning (nr. 1398) fra Domstolenes Strukturkommission. Hovedindholdet heraf er forslag om reduktion af antallet af byretskredse fra de nuværende 85 til 25 med ansættelse af mindst 6-8 dommere i hver af disse nye og større kredse og med en ny ledelsesstruktur. I april 2001 kom der endvidere en lige så omfattende betænkning (nr. 1401) fra Retsplejerådet om reform af den civile retspleje.

\section{Pressen og domstolene}

Et af de grundlæggende principper i (straffe)retsplejen er, at offentligheden skal have mulighed for at vide (kontrollere), hvad der foregår. Mediernes medvirken til udbredelse af kendskabet til bl.a. straffesager er i praksis en forudsætning for offentlighedsprincippets gennemførelse, da det er begrænset, hvor mange mennesker der kan udnytte adgangen til personligt at overvære retsmøder. På denne baggrund udkom i 1997 en betænkning (nr. 1330) vedrørende samarbejdet mellem retterne og pressen, der resulterede i ændrede regler i retsplejeloven på dette område (lov nr. 362 af 2.6.1999). Herefter har redaktører og redaktionelle medarbejdere såvel ved de skrevne medier som ved radioog fjernsynsforetagender fået adgang til at udtale sig, før retten beslutter dørlukning, referatforbud og navneforbud. Der er endvidere åbnet adgang til aktindsigt i form af gennemsyn af anklageskrift og visse andre dokumenter i sagen og til gennemsyn af dom- og retsbogen, når sagen er afsluttet. Endelig er det nu tilladt at tegne i retssalen, og der er åbnet mulighed for "undtagelsesvis" efter rettens nærmere bestemmelse at lave TV-optagelser af retsmøder. Hertil kommer en udvidelse af mediernes kildebeskyttelse i forbindelse med den almindelige vidnefritagelse for redaktører og redaktionelle medarbejdere.

\section{Efterforskning af kriminalitet}

Diskussionen om balancen mellem på den ene side effektive midler til bekæmpelse og efterforskning af kriminalitet og på den anden side borgernes beskyttelse mod myndighedernes indgreb $\mathrm{i}$ privatliv og ejendom foregår hele tiden. På ét område er balancen efter mange kritikeres mening tippet i retning af krænkelser af menneskerettighederne. Danmark er nemlig gentagne gange blevet kritiseret for overdreven brug af varetægtsfængsling under politiets efterforskning i almindelighed og isolation i forbindelse med varetægtsfængsling i særdeleshed. Således anbefalede FN's Menneskerettighedskomite i 1996 Danmark at overveje at tage de eksisterende regler for varigheden af dette indgreb op til overvejelse med henblik på en revision, idet Menneskerettighedskommissionen anser langvarig fængsling, hvor den indsatte ingen kontakt har med omverdenen, for i sig selv at udgøre en form for grusom, umenneskelig og nedværdigende behandling. I 1997 blev Danmark tilsvarende kritiseret af Den europæiske Komite for Forebyggelse af Tortur og Umenneskelig Behandling, der opfordrede til indførelse af en tidsbegrænsning for den samlede periode $\mathrm{i}$ isolation. Samme år kom der en lignende opfordring fra FN's Torturkomite. To videnskabelige rapporter fra henholdsvis 1994 og 1997, begge bestilt af Retsplejeudvalget, konkluderer enslydende, at varetægtsfængsling i isolation "indebærer en belastning og risiko for forstyrrelse af det psykiske helbred". I sidstnævnte rapport tilføjes det: "Det må på den baggrund lægeligt og psykologisk anbefales, at man ikke øger belastninger forbundet med varetægtsfængsling ved at anvende isolation". På trods heraf antages det i betænkning om varetægtsfængsling $\mathrm{i}$ isolation (nr. 1358/1998), at den danske brug af isolation inden for retsplejelovens rammer generelt ikke vil blive anset for stridende mod den europæiske menneskerettighedskonvention, og det foreslås, at ikke alene bør der også i fremtiden være adgang til 
isolation, men i visse tilfælde uden tidsbegrænsning. I den endelige udformning af ændrede regler på områet (lov nr. 428 af 31.5.2000) er der indført forskellige tidsgrænser alt efter, hvilken maximumsstraf den påsigtede forbrydelse kan medføre ifølge straffeloven. Hvis sigtelsen kan medføre fængsel i 6 år eller derover, må isolation som udgangspunkt ikke finde sted i mere end 3 måneder i sammenhæng, men retten kan "undtagelsesvis" tillade, at perioden udstrækkes yderligere (uden begrænsning), "hvis hensynet til forfølgningen gør fortsat isolation påkrævet, uanset den tid arrestanten hidtil har været isoleret" (retsplejelovens $\S 770 \mathrm{~b}$, stk. 3). Desuden er der indført en regel i straffelovens $\S 86$, stk. 1, om, at der skal afkortes et antal dage i strafafsoningen svarende til en dag for hver påbegyndt tidsrum af 3 døgn i isolation. Der er stillet forslag fra venstrefløjen i Folketinget om nedsættelse af et hurtigtarbejdende udvalg med henblik på at afskaffe isolationsfængsling (beslutningsforslag B 157 af 23.3.2001).

Et spørgsmål, der har været særlig livligt debatteret, er varetægtsfængsling $\mathrm{i}$ isolation af unge under 18 år. I 1999 udtalte Højesteret, at denne praksis ikke er i strid med FN's konvention om barnets rettigheder eller Den europæiske Menneskerettighedskonvention (Ugeskrift for Retsvæsen 1999.1415 H). Det nævnte lovforslag opretholdt da også muligheden, men med en absolut tidsgrænse på 8 uger i sammenhæng, og loven er vedtaget i overensstemmelse hermed. Red Barnet har truet med at indklage Danmark for Den europæiske Menneskerettighedsdomstol i Strassbourg næste gang, der foreligger en konkret sag om isolationsfængsling af "en ung under 18 år under efterforskningen. Formanden for regeringens Børneråd har kaldt det "uværdigt og krænkende" og mener, at der klart er tale om et brud på FN's konvention om barnets rettigheder. I løbet af foråret 2001 er der fra den politiske venstrefløj i Folketinget fremsat flere forslag til begrænsning i brugen af varetægtsfængsling $\mathrm{i}$ isolation, herunder et totalt forbud, hvis arrestanten er under 18 år (L 196 af 23.3.2001).

Varetægtsfængsling, herunder i isolation, er det mest indgribende tvangsmiddel, som er til rådighed under politiets efterforskning af forbrydelser, og selv om der nu er sat visse tidsgrænser for dette indgreb, kan der næppe siges reelt at være sket indskrænkninger. I praksis er brugen af isolation som sådan dog kraftigt reduceret siden de omtalte ændringer. Som nævnt i N.T.f.K. nr. 4/1999 er retsplejelovens regler om politiets beføjelser under efterforskningen også på andre områder blevet ændret (lov nr. 411 af 10.6.1997). Det drejer sig bl.a. om reglerne for ransagning og telefonaflytning, der i den nye udformning er blevet yderst detaljerede og temmelig komplicerede. Langt hen ad vejen er der tale om lovmæssig legitimering af en i forvejen bestående praksis. Der er således nu direkte hjemmel til hemmelig ransagning, såfremt det er "af afgørende betydning for efterforskningen, at ransagningen foretages, uden at den mistænkte eller andre gøres bekendt hermed". Det gælder kun i forbindelse med en lille gruppe alvorlige sager, herunder narkotikakriminalitet, der skal på forhånd være afsagt retskendelse om hemmeligholdelsen, og der skal være beskikket en advokat for den, hvis husrum mv. skal ransages på denne måde (retsplejelovens § 799).

Som et led i politiets forbedrede muligheder for at efterforske kriminalitet er det vedtaget, at der skal oprettes et centralt dna-profilregister. Det skal tjene som internt arbejdsregister for politiet i forbindelse med identifikation af personer og består af en "persondel" med dna-profiler, som kan identificeres på person, og en "spordel" med dna-profiler, som ikke kan identificeres på person. Oplysninger i registerets persondel skal straks slettes, når sigtelsen opgives som grundløs. Oplysningerne skal endvidere slettes, når der er forløbet 10 år fra frifindelse, påtaleopgivelse eller tiltalefrafald uden vilkår, eller den registrerede person er fyldt 70 år. I disse tilfælde kan sletning dog undlades, "hvis det efter en konkret vurdering undtagelsesvis findes nødvendigt at opretholde registreringen". Især denne del af loven er blevet stærkt kritiseret. Hvis en person er frifundet eller påtale er opgivet - som regel på grund af bevisets stilling - kan det efter kritikernes mening ikke være rimeligt at opbevare dna-materiale fra dem. Det viser ifølge en forsvarsadvokat, at politiet i virkeligheden betragter tidligere sigtede som skyldige, som der blot ikke har kunnet samles tilstrækkeligt bevismateriale imod, men at det nok en anden gang skal lykkes at fælde dem. Man kan tilføje, at Folketinget ved lovens vedtagelse understøtter denne opfattelse. Oplysninger om domfældte slettes senest 2 år efter hans/hendes død. Videregivelse af oplysninger fra registeret må 
kun ske til nærmere angivne myndigheder og institutioner, men den registrede kan ved personlig henvendelse til politiet få mundtlig underretning om de oplysninger, der er registret om ham/hende selv.

Med lov nr. 411 af 10. juni 1997 blev der i retsplejeloven endvidere bl.a. indført udvidet adgang til telefonaflytning og lempelse i muligheden for at anvende såkaldte tilfældighedsfund som bevis. Andre ændringer i retsplejeloven er sket med lov nr. 229 af 21.4.1999, der bl.a. giver politiet hjemmel til under visse forudsætninger at foretage fotografering eller iagttagelse ved hjælp af kikkert eller andet apparat af personer, der befinder sig i en privat bolig.

\section{Politiet}

Politiets faglige organisationer i Danmark deltager gerne i den kriminalpolitiske debat. I 1995 udsendte Dansk Kriminalpolitiforening sit eget kriminalpolitiske program. Programmet er på den ene side præget af den opfattelse, at politi og anklagemyndighed ikke har ressourcer nok til effektiv kriminalitetsbekæmpelse, og at "den kriminalpræventive effekt, som frihedsstraffene kunne have, mister sin effekt ved den måde, hvorpå straffesystemet administreres", at der tages for lidt hensyn til ofre og vidner, at "fremtidige tiltag, der tager sigte på yderligere styrkelse af sigtedes/tiltaltes rettigheder, skal undergå nøjere overvejelser, idet der bør foretages en reel vægtning af hensynet til den mistænkte contra hensynet til samfundets lovlydige majoritet", og at den kriminelle lavalder helt bør fjernes. På den anden side siges det også, at "narkomani i sig selv må betragtes som en sygdom og dermed som et socialt og sundhedsmæssigt problem, og ikke alene et kriminelt problem", at "det ikke er hensigtsmæssigt for nogen blot at anbringe børn og unge i fængsler eller fængselslignende institutioner", og at det kriminalpræventive arbejde bør forstærkes. I 1999 lancerede Dansk Politiforbund en annoncekampagne for øgede ressourcer til politiet. Den blev stærkt kritiseret for at spille på ældre menneskers frygt for kriminalitet.

I 1998 blev der iværksat et 3-årigt forsøgsprojekt med nærpoliti i hele eller dele af 6 politikredse (København, Frederiksberg, Helsingør, Roskilde, Esbjerg og Randers). Hensigten er at afprøve forskellige modeller for nærpoliti. Projektet følges tæt rent forskningsmæssigt, og der foreligger en midtvejsevaluering.

Politiets håndtering af de uroligheder, der opstod på Nørrebro i København om aftenen og natten efter den danske folkeafstemning om Maastricht-traktaten den 18. maj 1993, affødte i alt seks rapporter, to fra den daværende rigsadvokat, to fra den daværende politidirektør i København, én fra Folketingets Ombudsmand og endelig i 2000 én fra den undersøgelseskommission, som i 1996 fik til opgave at klarlægge, hvad der fik politiet til at affyre 113 skud (heraf nogle horisontalt) og kaste brosten mod demonstranterne. Kommissionens opgave har også været at undersøge forløbet omkring rigsadvokatens to rapporter, der blev kraftigt kritiseret af ombudsmanden. Kommissionens rapport munder ud $i$, at der intet er at kritisere, og at der derfor heller ikke er grundlag for et retligt ansvar. Denne såkaldte "Nørrebro-sag" har imidlertid for alvor sat det spørgsmål på dagsorden, hvem der bør foretage undersøgelser af politiets adfærd.

\section{Referencer:}

1. Nielsen, Beth Grothe (2001a): Forsøgsordningen med behandling af seksualforbrydere. I Ugeskrift for Retsvæsen 2001B s. 155-159.

2. Nielsen, Beth Grothe Nielsen (2001b): Behandling af seksualforbrydere i Canada og Danmark. I Greve, Nielsen \& Snare (red.): Nytter det? Mosaik om kriminalforsorg og kriminalpolitik. København/Jurist- og Økonomforbundets Forlag.

Adresse: Århus Universitet

Juridisk Institut

8000 Århus C.

e-post: bgn@jura.au.dk 